\title{
Understanding perennial wheat adoption as a transformative technology: evidence from the literature and farmers
}

\author{
Jelili Adebiyi ${ }^{1}$, Laura Schmitt Olabisi ${ }^{1, *}$ and Sieglinde Snapp ${ }^{2}$ \\ ${ }^{1}$ Department of Community Sustainability, Michigan State University, East Lansing, MI 48824, USA \\ ${ }^{2}$ Department of Plant, Soil and Microbial Sciences, Michigan State University, East Lansing, MI 48823, USA \\ *Corresponding author: schmi420@msu.edu
}

Accepted 19 April 2015; First published online 22 June 2015

Preliminary Report

\begin{abstract}
Perennial grain crops are an example of a 'transformative technology,' in which the functionality and science of the technology differ in a fundamental manner from conventional grain crops. A review of the literature indicates that the motivation for farmer adoption of transformative technologies is complex and poorly understood. At the same time, many studies have found concern and awareness about environmental issues to be significantly and positively correlated with the adoption of no-till agriculture, organic farming and agroforestry. Building on these insights, we conducted an ex ante study of perennial wheat adoption among 11 farmers from Michigan and Ohio. Perennial wheat is not yet commercially available, so a semi-structured interview format was chosen to allow for in-depth discussions of the crop's potential characteristics and uses. Consistent with the literature on transformative technology adoption, farmers who approached us to learn more about perennial grains described soil and environmental quality as their primary motivations for doing so. Farmers suggested a total of ten different uses for perennial wheat, only one of which was mentioned specifically by interviewers. This diversity of proposed uses implied a wide range of criteria for adoption. A striking result was that the ability of perennial wheat to compete with annual wheat on the basis of yield, a focus of researchers, was brought up by only one of the interviewees, as many farmers proposed perennial wheat as a means of solving a problem for which no other crop provided an adequate solution, often by planting perennial wheat on an under-used or marginal area of the farm. This is suggestive that interacting with farmers could alter priorities in perennial grain improvement, as has occurred in other radically transformative agriculture technologies.
\end{abstract}

Key words: perennial wheat, transformative technologies, technology adoption, soil quality, farmer decision making

\section{Introduction}

\section{Perennial grains}

Perennial grain crops have been proposed as a transformative means to conduct agriculture, one that has potentially radically improved ecosystem services compared with their annual counterparts, including carbon sequestration, reduced nitrate leaching and erosion reduction (Jackson, 2002; Cox et al., 2006; Culman et al., 2013). In the USA, breeding programs focusing on hybridization between annual wheat and its perennial relatives are the most advanced in development of a perennial grain crop (Jaikumar et al., 2012). Perennial wheat is not yet commercially available, but for its potential benefits to be realized, farmers would have to be interested in adopting it. Would American wheat farmers switch from annual to perennial varieties, or grow both types? Would farmers who do not grow wheat currently be interested in a perennial wheat?

To date, studies examining these types of questions have focused solely on the economic potential of perennial wheat to replace annual wheat (Bell et al., 2008). The economic competitiveness of perennial grain crops compared with their annual counterparts will certainly be a major driver of adoption, but not the only driver. Restricting famer considerations of adoption potential to one dimension (the expected profit approach) is not consistent with the literature on adoption of transformative agricultural technologies, which suggests that farmers' decisionmaking processes around adoption of these technologies are complex and dynamic. Moreover, farmers often modify agricultural technologies to make them suitable for their own farming system. Replacement of annual 
varieties may not be the only, or even the primary, use for perennial wheat.

As plant-breeding efforts have made progress in the development of perennial wheat and closely related cereal relatives, there have been a number of high-profile reviews calling for major investments in these efforts as a transformative, environmentally friendly form of field crop agriculture. The benefits of perennial grains for reducing nitrate leaching, enhancing the biodiversity of agricultural landscapes, sequestering carbon, reducing erosion, reducing labor and input costs and improving resilience to climate change have all been proposed, and some of these benefits have been demonstrated on the field scale (Glover et al., 2010; Jaikumar et al., 2012; Pimentel et al., 2012; Culman et al., 2013). However, the focus of efforts to develop a new perennial growth form of wheat has privileged grain yield, and to a lesser extent grain quality (Cox et al., 2006; Murphy et al., 2009, 2010; Jaikumar et al., 2012; Hayes et al., 2012), over the potential environmental benefits these crops would provide both on-farm and across the landscape.

Our goal was to elucidate the adoption and potential uses of perennial wheat, as a case study of a transformative technology. We conducted a review of the agricultural technology adoption literature for three transformative systems, and conducted a series of semi-structured interviews on perennial wheat potential with farmers in Michigan and Ohio. Our objectives were to understand the criteria farmers might use in deciding whether and how to adopt perennial grains, and the ways in which they envisioned these grains fitting into their farming operation.

\section{Agricultural technology adoption studies}

Studies on the adoption of agricultural technologies can be broadly classified into two, ex ante and ex post. The latter are studies conducted after a technology has been adopted by farmers to determine why a technology was adopted, disadopted or not adopted (Lesser et al., 1999; Babu and Rhoe, 2003; Mercer, 2004; Sirrine et al., 2010). Because perennial grains are a technology that is still under development, in this literature review we focus on ex ante adoption studies. Ex ante studies are conducted prior to the introduction of new agricultural technologies (Pingali et al., 2001). Such studies may be carried out before, during, or after on-farm trials of agriculture innovations (Franzel and Scherr, 2002) or before their commercialization (Babu and Rhoe, 2003). The focal point of ex ante studies is to gain insight into the factors which, hypothetically, may affect the acceptance of new farm technologies and determine their adoption potential (Franzel and Scherr, 2002; Pierpaoli et al., 2013). This may extend to assessing and eliciting information on the farmers' perception of the technology (Pingali et al., 2001), and the technology's likely economic impacts before their introduction (Alston et al., 2003); or to discern and define, ex ante, the agronomic, socio- economic, ecological and biophysical factors that may inform the likelihood to adopt (or not) (Franzel and Scherr, 2002). Ex ante studies are also used to obtain information that improves the performance of the technology, enhances its acceptability, and overall fosters the innovation's successful transference to farmers (Dearing and Meyer, 1994; Franzel and Scherr, 2002); to determine how the innovation potentially fits into farmers' production goals and resource allocation decision-making; and to gather information needed to decide and ensure that the technology in a notional state is appropriate to farmers' specific needs and their farming conditions (Mercer, 2004).

\section{Adoption of transformative agriculture technologies}

Perennial grains are expected to be a 'radical', or transformative technology, meaning that their architecture, functionality, component principles and underlying science markedly depart from existing agricultural systems. This conception of radical agricultural innovations draws on Rennings et al. (2013). Here we examine the literature on adoption of other transformative technologies, to gain insights on how perennial grains might be adopted.

No-till cultivation is another example of a radical agriculture innovation (Coughenour, 2003; Huggins and Reganold, 2008), which fits the context of this study. No-till represents a clear departure from traditional farm practices, which require seasonal tilling of the land multiple times, to prepare for planting, for nutrient release and during the growing season for weed control (Huggins and Reganold, 2008). In contrast, no-till technology involves no or very little soil disturbance and uses equipment and chemistry markedly different from traditional agricultural technologies. Organic farming systems and agroforestry are two other radical agricultural innovations (Morgan and Murdoch, 2000; Vanloqueren and Baret, 2009). Organic agriculture is considered a radically altered system because it is based on principles, practices, knowledge systems, values and perceptions about soil, plants, farmers, and environmental relations which are clearly distinct from conventional agriculture's (Morgan and Murdoch, 2000). Agroforestry has also been so identified because it is based on a farming practice which deliberately incorporates perennial woody plants into cropped fields. Like agroforestry systems, perennial grain systems may demonstrate what Jaikumar et al. (2012) describe as 'delayed reproductive investment' (p. 1716). All of these transformative technologies are widely associated with gains in ecosystem services.

Having discussed why we chose adoption studies on notillage, agroforestry and organic farming systems for review, we shall now focus on the drivers of their adoption.

Studies have investigated how the awareness of soil problems such as soil erosion impact adoption of radical agricultural technologies. Vitale et al. (2011) and Andrews 
et al. (2013) found that soil erosion is a significant and positive determinant of farmers' decision to adopt notill conservation technology. However, in a study which examined the factors which determine the use of conservation tillage in Australia, D'Emden et al. (2008) found that the awareness of, and the proneness of soils to erosion was insignificant to the adoption of no-till. Similarly, Bultena and Hoiberg (1983) found that perception of, and awareness of soil erosion problems was not a determinant of Iowan farmers' decision to adopt or not to use conservation tillage practices which included no-till. Their study revealed that, 'early adopters and non-adopters both perceived soil erosion as being less of a problem than did late adopters' (p. 283). The authors reasoned that considerable improvements to the soils of early adopters may help explain their findings. Conversely, in their study of farm forestry adoption in Australia, Race and Curtis (2007) found a positive relationship between landholders' decision to adopt agroforestry and soil erodibility concerns. A similar finding has been reported by Valdivia and Poulos (2009), whose studies examined the determinants of farmers' decisions to use agroforestry farming practices in Missouri, USA. Valdivia and Poulos further found the impact of soil problems and environmental problems to be significant, a finding which is akin to Trozzo et al. (2014). In line with this, McCann et al. (1997) found that farmers with a high awareness and concern for soil erosion are likely to adopt organic farming practices. Overall, most studies have found concern and awareness about soil erosion to be significantly and positively correlated with the adoption of no-till agriculture, organic farming and agroforestry.

Attitude toward risk and economic situation of producers have also received attention as explanatory drivers in the technology adoption literature. A study by McCann et al. (1997), found that organic farmers were more disposed to the risks associated with their adoption decisions, by, for example, accepting reduced yields and delayed return on their productive investment for future benefits. The willingness to take related risks has also been associated with adopters of no-till (Bultena and Hoiberg, 1983) and riparian buffer agroforestry practices (Trozzo et al., 2014). While organic producers may be willing to accept greater risk, they also are motivated by the potential for higher profit margins associated with organic products (McCann et al., 1997). In a corresponding finding, Peterson et al. (2012) found that the motivations of organic grain farmers in the USA extend beyond organics as a way of life to include profit maximization.

The literature on subsidies paints a different story; studies such as Andrews et al. (2013) have found no statistically significant relationship between the provision of economic incentives for environmental services, carbon storage and the adoption of no-till conservation tillage. This contrasts with the findings of Alavalapati et al. (2004), that incentive payments positively and significantly impact the likelihood of adoption of silvopasture agroforestry practices. However, an adoption synthesis study by Prokopy et al. (2008) found the relationship between profitability, incentive payments and the adoption of no-till to have both negative and positive correlations. In contrast, findings by Vitale et al. (2011) indicated that profitability significantly impacts the adoption of no-till. However, the cost of equipment is found to negatively impact the adoption of no-till (Vitale et al., 2011). Similarly, Andrews et al. (2013) found that reduction in labor and fuel cost help drive the adoption of no-till. Overall, a major implication of these findings is that the adopters of organic farming, no-till and agroforestry are not averse to taking risks for future returns on their investments (including returns to soil quality), and that market-based profitability, rather than government-provided incentives, is more likely to drive the economic aspects of farmers' adoption decisions.

The relationship of different agronomic and biophysical factors, such as soil type, soil compaction and drainage, slope, plant residue, and insect and disease problems to the adoption of no-till has also been reported. Soil types and soil compaction negatively affect the adoption of no-till in Oklahoma (Vitale et al., 2011). Likewise, Rahm and Huffman (1984) found that the adoption of no-till by Iowan corn farmers significantly depends on soil characteristics. The likelihood of no-till adoption has been found to be greater on rolling, lighter and welldrained soils (Vitale et al., 2011). A related finding has been reported by Andrews et al. (2013). However, Prokopy et al. (2008) found that higher slopes both negatively and positively correlate with the adoption of conservation tillage practices, including no-till. Finally, residue management limits and negatively affects the adoption of no-till, due to the associated difficulties with soil management, plant establishment and insect infestation problems (Vitale et al., 2011).

The relationship between environmental concerns, land stewardship, values and the adoption of transformative agricultural technologies has also been investigated. A study conducted on organic and conventional farmers in three West German states found a statistically significant relationship between farmers' environmental concerns and the adoption of organic agriculture (Best, 2010). In this context, the decision to adopt organic agriculture increases with farmers' environmental concerns and the latter helps in framing farmers' adoption decisions. However, the West German study also found that environmental concerns alone are not enough to predict organic agriculture adoption, and a key factor was if farmers found the decision to go organic "economically very attractive' (p. 464). A related finding has been reported by Peterson et al. (2012) and also by Lapple and Van Rensburg (2011) and others (Läpple, 2010; Kaufmann et al., 2011), who found that environmental concerns positively correlate with the organic agriculture adoption decision. 
Likewise, Arbuckle et al. (2009) found a strong positive association between environmental concerns and agroforestry adoption decisions of non-operator landowners in two Missouri watersheds. Valdivia and Poulos (2009) also found a significant relationship between these two variables. Prokopy et al. revealed that environmental concerns exhibit both negative and positive correlation with the no-till adoption decision (Prokopy et al., 2008). This is similar to the finding by Lahmar (2010) that environmental concerns were not pivotal to European farmers' decisions to adopt conservation agriculture, including no-till. Ryan et al. (2003) reported that farmers who are good land stewards and are innately attached to their lands are more likely to adopt no-till, while Andrews et al. (2013) found that those who exhibited strong concerns for soil compaction and soil drainage are likely to adopt soil conservation practices, including no-till. However, Vitale et al. (2011) reported no clear association between awareness of environmental consequences and the adoption of soil best management practices, including no-till.

Other factors that might influence a farmer's decision to adopt organic agriculture include placing a high value on the quality of farm products (Kallas et al., 2010) or on soil management (Kaufmann et al., 2011) and soil quality; or concern about the ecological and human health effects of agro-chemical use (McCann et al., 1997; Kaufmann et al., 2011). Kaufmann et al. found that positive perceptions about the impact of organic farming methods on human, wildlife and plant health significantly correlates with organic adoption decisions (Kaufmann et al., 2011). Ryan et al. found that among the major reasons farmers in Midwestern riparian zones adopt woody vegetation cover and no-till are the reduction of agrochemical use, the protection of stream health, and to make their farms appear well-managed (Ryan et al., 2003). Trozzo et al. (2014) as well as Strong and Jacobson (2006) have reported that farmers who adopt agroforestry consider it to have offered beneficial environmental impacts such as water quality enhancement, wildlife preservation and soil protection.

Thus far, the discussion has focused on a synthesis of some of the factors that determine the adoption decisions for three transformative agriculture technologies we selected for review. The effects of variables such as farm size, adopters' economic orientation, environmental concerns, land stewardship, values, and agronomic and biophysical factors on adoption decisions appear to be complex. One reason for this may be spatial non-stationarity (Taus et al., 2013), meaning that these variables have differential impacts on different actors. Spatial non-stationarity is a "condition in which a simple "global" model cannot explain the relationships between some sets of variables' (Brunsdon et al., 1996, p. 281). For example, spatial non-stationarity may explain why different studies have reported different findings as to the effect of farm size on transformative technology adoption.
In addition, farmers' decisions to adopt transformative technologies may be informed by several motivations interacting with one another across multiple points in time- that is, famers' decisions are both complex and dynamic, as are the circumstances under which they make decisions. For example, Vitale et al. (2011), Lapple and Van Rensburg (2011) and Best (2010), demonstrated that ideological commitments, economic motives and/or environmental concerns taken individually do not adequately predict the decision to adopt transformative technologies. Finally, differences in methodology may also help explain the complexity of the findings on factors contributing to adoption decisions. Knowler and Bradshaw (2007) observed that studies that use logit or probit models (a common tool in econometric analyses) 'are likely to ascribe greater influence to the variables "education" and "farm size" (p. 40). D'Emden et al. (2008), studying no-till adoption in Australia, found that while logit regression models returned education as a significant determinant of adoption decision, a duration analysis model based on the same data found otherwise.

Despite the indeterminate and occasionally contradictory nature of findings from the literature, there is consistent evidence that economic factors, farmers' values and concern about long-term soil health, farm size and attitudes toward risk all may influence the decision to adopt transformative technologies in different and interacting ways (Table 1). Concern about both soil erosion and environmental health are consistently, positively and significantly associated with adoption of organic agriculture and agroforestry. Concerns about soil erosion seem to drive no-till adoption, although the determinants of no-till adoption are complicated by their association with genetically engineered seed. This association likely explains the positive and negative associations with environmental concern which adopters of this technology display. Health concerns play a significant role in organic adoption decisions. The effects of farm size, economic priorities and risk attitudes on the adoption of transformative technologies appear to be more complex and context-dependent. None of these factors in isolation is likely to be sufficient to explain an adoption decision. Moreover, the fact that many of these explanatory factors (soil quality, farmer attitudes and farm size) change over time, partly in response to adoption decisions, highlights the need to adopt research methods that consider farms as adaptive, dynamic systems.

The literature review informed our targeted selection of interviewees and interview questions. Overall, early adopters of transformative technologies appear to be concerned about environmental quality, and willing to take the risk of deferred financial gain in order to achieve soil health and long-term investment goals. We therefore felt it was important to recruit farmers to our study who are already experimenting with alternative technologies, and who are therefore likely candidates for early adoption 
Table 1. Summary of the literature review on adoption of transformative technologies (no-till, organic and agroforestry) as a function of farm and farmer characteristics.

\begin{tabular}{|c|c|c|c|c|}
\hline & Positive correlation & Negative correlation & Significant & Not significant \\
\hline \multicolumn{5}{|l|}{ Farm size } \\
\hline Organic & $\mathrm{X}$ & $\mathrm{X}$ & $\mathrm{X}$ & $\mathrm{X}$ \\
\hline No-till & $\mathrm{X}$ & $\mathrm{X}$ & $\mathrm{X}$ & $\mathrm{X}$ \\
\hline Agroforestry & $\mathrm{X}$ & $\mathrm{X}$ & & \\
\hline \multicolumn{5}{|l|}{ Soil erosion } \\
\hline Organic & $\mathrm{X}$ & & $\mathrm{X}$ & \\
\hline No-till & $\mathrm{X}$ & & $\mathrm{X}$ & $\mathrm{X}$ \\
\hline Agroforestry & $\mathrm{X}$ & & $\mathrm{X}$ & \\
\hline \multicolumn{5}{|c|}{ Risk/economic orientation } \\
\hline Organic & $\mathrm{X}$ & $\mathrm{X}$ & & \\
\hline No-till & $\mathrm{X}$ & $\mathrm{X}$ & $\mathrm{X}$ & $\mathrm{X}$ \\
\hline Agroforestry & $\mathrm{X}$ & & $\mathrm{X}$ & \\
\hline \multicolumn{5}{|c|}{ Environmental concern/land stewardship } \\
\hline Organic & $\mathrm{X}$ & & $\mathrm{X}$ & $\mathrm{X}$ \\
\hline No-till & $\mathrm{X}$ & $\mathrm{X}$ & & \\
\hline Agroforestry & $\mathrm{X}$ & & $\mathrm{X}$ & \\
\hline \multicolumn{5}{|c|}{ Soil types/drainage/compaction } \\
\hline \multicolumn{5}{|c|}{ Organic } \\
\hline No-till & $\mathrm{X}$ & $\mathrm{X}$ & $\mathrm{X}$ & $\mathrm{X}$ \\
\hline Agroforestry & & & & \\
\hline \multicolumn{5}{|c|}{ Health considerations/product quality } \\
\hline Organic & $\mathrm{X}$ & & $\mathrm{X}$ & \\
\hline No-till & $\mathrm{X}$ & & & \\
\hline Agroforestry & $\mathrm{X}$ & & & \\
\hline
\end{tabular}

The 'significant' and 'not significant' columns refer to the statistical significance of the independent variable (e.g., farm size and environmental concern) for the studies summarized in the table (most studies used multiple regression).

of perennial grains. In addition, we wanted to keep the interviews relatively unstructured, because the sometimes contradictory nature of the literature on transformative technology adoption reveals the need for farmer-led narratives of how adoption decisions are made.

\section{Methods: farmer interviews}

We recruited farmers through conferences and growers' meetings in Michigan between January and March, 2012. We targeted a range of venues to attract conventional wheat growers, pasture-based livestock farmers, small, alternative and family farm producers. At each meeting, members of the research team set up a table with a poster and some information on the perennial wheat breeding program, and invited interested farmers to learn more about the research and to sign up to be interviewed. We emphasized that the perennial wheat crops were in the developmental phase, and would not be ready for on-farm use in the near future. Each meeting yielded a sign-up sheet with names and contact information of farmers who were interested in being interviewed about how they might use perennial wheat.

Interviewees were selected from the sign-up sheets to represent a range of farm operation types (large, small, organic, conventional, pasture-based, grain-based and integrated crop/livestock) (Table 2). A total of 11 interviews were conducted between March and April, 2012. Interviews typically took approximately $1 \mathrm{~h}$, and were conducted by two or three interviewers. Interviewees were compensated US\$5 for their time. The interviews were semi-structured, and were recorded with interviewees' permission (see Appendix A for interview guide). Farmers were asked about the size of their farm, crops grown, inputs used, history of farming, priorities for farm management, and financial/personal goals for their farming operation. They were also asked about their interest in perennial wheat, how they might use it on their farms, what characteristics it would need to have in order for them to be interested in planting it, and what benefits or challenges such a crop might provide.

The interviews were transcribed in summer, 2012. All interviews were read over by multiple members of the research team to clarify technical information and resolve uncertainties and inconsistencies. A coding table was codeveloped by several research team members to address the research questions (Appendix B). The interviews were then coded using NVivo software in late summer, 2012, and two coded interviews were checked for accuracy by the lead author. Summary documents were prepared containing all potential uses of perennial wheat 
Table 2. Descriptive data on farmer interviewees.

\begin{tabular}{|c|c|c|c|c|c|}
\hline & Years farming & Crops grown & Livestock & Area (acres) & Farm type \\
\hline Farmer 1 & 10 & Wheat, soybeans, corn & Goats, sheep & 12 (pasture) & Conventional \\
\hline Farmer 2 & 40 & Hay, vegetables & Dairy cattle & Varies & Conventional \\
\hline Farmer 3 & 6 & Hay, fruit trees & Chickens, dairy cattle & 23 & Organic \\
\hline Farmer 4 & 50 & Rye, alfalfa & & 120 & Organic \\
\hline Farmer 5 & $>20$ & Vegetables & Pigs & 14 & Organic \\
\hline Farmer 6 & 42 & Fruit trees, wine grapes & & Varies & Conventional \\
\hline Farmer 7 & 39 & Corn, wheat, soybeans & & 3000 & Conventional \\
\hline Farmer 8 & 63 & Corn, wheat, soybeans & Hogs & 500 & Conventional \\
\hline Farmer 9 & 70 (three generations) & Corn, wheat, soybeans, black beans & & 1080 & Organic \\
\hline Farmer 10 & 'Whole life' & Beans, various small grains & Dairy cattle & 200 & Organic \\
\hline Farmer 11 & 12 & Fruit trees & Pigs, sheep & 9 (open) & Organic \\
\hline
\end{tabular}

mentioned by interviewees, and all perceived or desired characteristics of perennial wheat described by farmers.

\section{Results}

Farmers in our study were clearly motivated by concerns about soil and environmental quality on their farms. Farmers' perception that perennial varieties of wheat would exhibit these traits (soil-improving; environmentally sound; compatible with organic farming) motivated them to approach us to learn more about the crop. For example:

\section{I2: What other benefits do you think a crop like this might provide for your farm?}

F1: I think just its perennial nature. Having its roots there all the time. Again, good for the bacteria and fungus, not disturbing the soil. Getting back to the whole, whole biology of the soil aspect is really important, and that's one thing that I see is a really promising aspect of this.

F9: When you are organic you need that soil life a LOT more. And that is a huge thing for me; not tilling the soil is good for soil life too. So I see advantages there.

This focus on soil health and stewardship ethic on the part of farmers interested in this potentially transformative technology is consistent with the literature review described above (Soltani et al., 2014). Farmers interested in perennial wheat appeared to exhibit characteristics of farmers who adopt both no-till and organic technologies, given their concern for improving soil health, conserving soil and producing healthy foods (Table 1). One farmer mentioned being influenced by a vision of agriculture as mimicking the biology of 'natural' ecosystems, which has also motivated the development of perennial grains:

F1: Well I've been really interested in this for quite a while; I had met Wes Jackson a few times at conferences ... That's really peaked my interest a lot. I had a strong interest in prairie ecosystems, and I'm trying to look at is how what I'm doing with my biology mimics what's going on in prairies because I think fields are pretty much prairies, even though it was woods at one time.
Farmers suggested a total of 11 potential uses of perennial wheat, only one of which (dual-purpose grain/forage) was mentioned specifically by interviewers (Table 3 ). Along with these potential uses, they described the reason(s) why a perennial grain might be desirable for that use, and the characteristics it would have to have in order for the farmer to be interested in planting it. High grain yield was considered a desirable characteristic for only one potential use (dual-purpose grain/forage). This is in marked contrast to previous studies of the adoptability of perennial wheat, which have assumed that grain yield is a necessary characteristic farmers look for when deciding to substitute perennial wheat for annual wheat (Bell et al., 2008). Only one group of interviewees, a family of farmers growing annual wheat in a corn-wheatsoybean rotation, stated that the total monetary value of the grain and forage produced from perennial wheat would have to be comparable with the value of annual wheat grain yields before they would consider adoption:

F7b: But if you could get it to where the yield is such ... that the balance between the yield and selling the green matter is equal to or better than annual wheat - then I think you're right on track.

Many of the proposed uses did not involve a substitution of perennial wheat for a cash crop already grown on-farm. Rather, they proposed perennial wheat as a means of solving a problem for which no other crop provided an adequate solution, often by planting perennial wheat on an underused or marginal area of the farm. For example, one farmer suggested that perennial wheat could be planted between his organic bean fields and his conventionally grown neighbor's fields as a buffer strip:

F9: ... put this wheat in the buffer I would have one planting for multiple years so I wouldn't have to clean my planting equipment ... cause right now, we don't grow any cash crops on the buffers.

In this case, the farmer was using buffer strips to grow forage for his hired workers' goat, but he saw perennial wheat as a potential means to cultivate both grain and forage on this underutilized piece of land. 
Table 3. Proposed on-farm uses, desirable aspects and characteristics of perennial wheat described by Michigan and Ohio farmers.

\section{Proposed use of perennial}

wheat

Dual purpose (grain harvest for humans and forage) (5)

Dual purpose (grain harvest for animal feed and sileage) (1)

Forage (4)

Dual purpose (forage for cows, grain for chickens) (1)

Mulch for fruit trees (1)

Grain for artisan bread (1)

Cover crop (4)

Windbreak (1)

Buffer strip between organic, conventional fields (1)

Plant on conservation reserve program land (1)
Desirable aspects
Necessary characteristics

Promoting soil biodiversity; mimicking 'natural' ecosystems; cost savings; reduced labor; potential for manure application

Providing both grain and forage

Mimicking 'natural' ecosystems

Micro-nutrients, minerals

Soil structure enhancement; low maintenance; developed root structure

Reduced labor; potential \$ from currently unproductive land; choke out weeds, erosion control, reduced cost of cleaning equipment; soil biodiversity enhancement

Potential \$\$ from currently unproductive land

Abundant grain yield; producing forage at time when other plants are not producing (e.g., early in spring or late in fall); grain quality; green matter production; disease resistance

Presence of micronutrients that animals, consumers want

Timing of seed production

Health benefits for consumers

Disease resistance

The 'necessary characteristics' column lists attributes the crop would have to have in order for farmers to consider adopting it for the proposed use. The number in parentheses under the 'proposed use' column indicates the number of farmers who suggested that use.

Farmer responses also reflected a growing trend in direct marketing of farm products to consumers and local intermediaries. Several responses indicated an interest in perennial wheat as a mechanism to provide niche products to consumers interested in healthy, locally produced foods. For example:

F8: ... have you looked into the nutrient content - you mentioned not having gluten, are there other ... something that's really high end or low end or whatever that will help sell the product?

Farmers asked multiple questions about the characteristics of perennial wheat. The function of these questions often appeared to be to 'think out loud' about how to fit the crop into their current farming systems For example, the following dialog occurred around whether perennial grains could be planted with a farmer's current equipment:

F1: You said the seed is a little bit smaller than annual wheat? I2: A little bit, yeah.

F1: So you plant with a grain drill? Or with a seeder, like you'd use with alfalfa and clover seed? Do you know?

I2: I think we used a seed drill...

F1: ... cause if you have a grain drill with a seeder, it usually can handle anything from the tiny clover to the soybeans.

\section{Discussion}

The fact that farmers listed multiple potential uses of perennial wheat, and discussed multiple criteria which could be satisfied in order for them to adopt the crop, is consistent with the complex nature of adoption decisions described in the literature on transformational technology adoption. Only one interviewee described yields comparable with annual wheat as a prerequisite for adoption of the hypothetical grain, and even in that context the total forage production in addition to the grain yields were considered an asset of a perennial wheat. Grain characteristics and growth characteristics were mentioned by all of the farmers in our interviews. Similar findings are widely reported in the participatory variety selection literature, as grain quality traits and growth habit have frequently emerged in farmer assessments of new crop varieties in a developing country context (Virk et al., 2005). Interestingly, in the USA, participatory plant breeding efforts to develop wheat and other crops for organic production systems have recently been implemented (Kandel et al., 2008), and yield has emerged as a key trait of concern for farmers, but other traits are as important. These have included protein grain content, seedling vigor and disease resistance. 
Although plant breeding efforts over many decades have addressed multiple simultaneous objectives, these have almost always had yield as a primary focus (Glover et al., 2010). Recent efforts to develop perennial wheat and perennial rye involve crossing of annual wheat and rye with wild relatives and selecting for improved grain yield (Acharya et al., 2004; Murphy et al., 2010). Intermediate wheatgrass is currently being domesticated through selection for high yield (Cox et al., 2006). Related agronomic research has also focused on yield (Jaikumar et al., 2012; Hayes et al., 2012). Disease resistance is another key objective of some perennial grain plant breeders (Cox et al., 2005). There is one report that highlights the characteristics of the grain and grain quality in novel perennial wheat lines (Murphy et al., 2009), and perennial regrowth vigor (Murphy et al., 2010), but there are few reported efforts in these areas. The results of this study imply that breeders may wish to consider developing multiple growth forms of perennial grains to address novel market niches, and that not all of these forms may need to be yield-competitive with annual grains in order for farmers to find them desirable (Table 3).

Farmers often adapt technologies for their own particular situations, rather than accepting the technology for its 'intended' use (Adegbola and Gardebroek, 2007). There is no reason to expect that perennial grain adoption will be different from other transformative technologies, based on the evidence from these interviews. A breeding program which seeks to optimize one characteristic of perennial wheat (yield, for example), without referencing the multiple potential uses farmers envision, would therefore miss opportunities for more widespread adoption.

The multiple potential uses of perennial wheat also shed light on why the technology adoption literature does not reach consensus on major determinants of transformative adoption. Farmers' decisions about technology adoption are highly contextual, and that context is dynamic. A study conducted as a snapshot of a farmer decision-making process will therefore yield different results across different types of systems and at different points in the adoption trajectory. This was highlighted through the dialogic nature of the interviews, in which farmers considered out loud how perennial grains could fit into their current farming systems, and asked questions about perennial wheat as they 'problem solved'. Some recent studies are incorporating methodologies which can accommodate the complex and dynamic nature of adoption decisions, such as agent-based modeling (Berger, 2001) or system dynamics modeling.

Because farmers self-selected into our study, only those who showed interest in adopting a perennial grain were interviewed. This necessarily biased our group of interviewees, as we did not include those who would not consider adopting a perennial wheat because its characteristics did not meet their adoption criteria. For example, no one from the conventional wheat growers' meeting ultimately agreed to be interviewed, although some gave us their contact information. The fact that conventional growers were not particularly interested in a perennial wheat is informative for our study in itself. As our literature review demonstrated, early adopters of radically different technologies in general tend to have (1) high environmental concern; and (2) a willingness to take risks of delayed returns in hopes of achieving long-term financial and soil health gains. While conventional wheat growers certainly display a range of these characteristics, it is possible that early adopters of perennial wheat will come from a smaller pool of farmers who are already experimenting with alternative technologies such as polycultures, rotational grazing and organic grain production. Adoption may spread more broadly once the benefits of growing perennial grains (in terms of soil health and possibly reduced labor) are demonstrated by these early adopters. It is therefore not surprising that our group of farmer interviewees was made up disproportionately of experimental farmers, who have used and adopted other transformational technologies on their farms. This type of farmer is likely to be the early adopter targeted for perennial wheat dissemination, so understanding their decision processes is important. Our interviewee pool was small, however, despite widespread recruiting efforts, so the innovative and experimental group of farmers represented in our interviews likely make up a small minority of all wheat farmers.

\section{Conclusions}

This is a novel ex ante study using interviews to gauge interest in and potential uses of perennial wheat among farmers in Michigan and Ohio. Using a semi-structured interview format allowed us to gain insight into farmer decisionmaking around the adoption of a radical new technology. Consistent with other studies of transformative technology adoption (agroforestry, organic agriculture and no-till), farmers mentioned multiple, interacting factors that would contribute both to their interest in learning more about perennial grains, and to their decision about whether or how to use perennial grains. These factors included interest in supporting production of environmental services on the farm, consumer preference, market availability, timing of crop emergence and regrowth, disease/pest resistance, and providing a new crop suited to marginal lands. In only one incidence was direct substitution for conventional wheat and yield mentioned. We conclude that breeding programs for perennial grains should take this complex decision-making into consideration, potentially by developing multiple products with different economic markets and on-farm uses. Furthermore, studies of perennial grain adoption will mischaracterize both potential adopters and potential uses of the crop if they rely purely on reductionist methods that emphasize one adoption criterion independent of other crop aspects. 
Acknowledgements. We would like to thank the Bill and Melinda Gates Foundation and the USDA Organic Agriculture Research and Extension Initiative for funding this research. We are also grateful to the farmers who participated in this study, and to Rebecca Wittman, Christine Sprunger, Siena Tinsley and Jennifer Meyer for assisting with data collection and transcription. Finally, we thank the anonymous reviewers whose comments improved this manuscript.

\section{References}

Acharya, S.N., Mir, Z., and Moyer, J.R. 2004. ACE-1 perennial cereal rye. Canadian Journal of Plant Science 84(3):819-821.

Adegbola, P. and Gardebroek, C. 2007. The effect of information sources on technology adoption and modification decisions. Agricultural Economics 37(1):55-65.

Alavalapati, J.R.R., Shrestha, R.K., Stainback, G.A., and Matta, J.R. 2004. Agroforestry development: An environmental economic perspective. Agroforestry Systems 61-2 (1):299-310.

Alston, J.M., Hyde, J., Marra, M.C., and Mitchell, P.D. 2003. An ex ante analysis of the benefits from the adoption of corn rootworm resistant transgenic corn technology. AgBioForum 5(3):71-84.

Andrews, A.C., Clawson, R.A., Gramig, B.M., and Raymond, L. 2013. Why do farmers adopt conservation tillage? An experimental investigation of framing effects. Journal of Soil and Water Conservation 68(6):501-511.

Arbuckle, J.G., Jr, Valdivia, C., Raedeke, A., Green, J., and Rikoon, J.S. 2009. Non-operator landowner interest in agroforestry practices in two Missouri watersheds. Agroforestry Systems 75(1):73-82.

Babu, S.C. and Rhoe, V.D. 2003. Assessing agricultural biotechnology: Applications of ex-ante and ex-post methods to genetically modified crops. Asian Biotechnology and Development Review 5:1-22.

Bell, L.W., Byrne, F., Ewing, M.A., and Wade, L.J. 2008. A preliminary whole-farm economic analysis of perennial wheat in an Australian dryland farming system. Agricultural Systems 96(1-3):166-174.

Berger, T. 2001. Agent-based spatial models applied to agriculture: A simulation tool for technology diffusion, resource use changes and policy analysis. Agricultural Economics 25(23):245-260.

Best, H. 2010. Environmental concern and the adoption of organic agriculture. Society and Natural Resources 23(5): 451-468.

Brunsdon, C., Fotheringham, A.S., and Charlton, M.E. 1996. Geographically weighted regression: A method for exploring spatial nonstationarity. Geographical Analysis 28(4):281-298.

Bultena, G.L. and Hoiberg, E.O. 1983. Factors affecting farmers adoption of conservation tillage. Journal of Soil and Water Conservation 38(3):281-284.

Coughenour, C.M. 2003. Innovating conservation agriculture: The case of no-till cropping. Rural Sociology 68(2):278-304.

Cox, C.M., Garrett, K.A., Cox, T.S., Bockus, W.W., and Peters, T. 2005. Reactions of perennial grain accessions to four major cereal pathogens of the great plains. Plant Disease 89(11):1235-1240.
Cox, T.S., Glover, J.D., Tassel, D.L.V., Cox, C.M., and Dehaan, L.R. 2006. Prospects for developing perennial grain crops. Bioscience 56(8):649-659.

Culman, S.W., Snapp, S.S., Ollenburger, M., Basso, B., and DeHaan, L.R. 2013. Soil and water quality rapidly responds to the perennial grain Kernza wheatgrass. Agronomy Journal 105(3):735-744.

D'Emden, F.H., Llewellyn, R.S., and Burton, M.P. 2008. Factors influencing adoption of conservation tillage in Australian cropping regions. Australian Journal of Agricultural and Resource Economics 52(2):169-182.

Dearing, J.W. and Meyer, G. 1994. An exploratory tool for predicting adoption decisions. Science Communication 16(1): $43-57$.

Franzel, S.C. and Scherr, S.J. 2002. Trees on the Farm: Assessing the Adoption Potential of Agroforestry Practices in Africa. CABI Publishing in association with the International Centre for Research in Agroforestry, Wallingford and New York. ix, 197 p.

Glover, J.D., Reganold, J.P., Bell, L.W., Borevitz, J., Brummer, E.C., Buckler, E.S., Cox, C.M., Cox, T.S., Crews, T.E., Culman, S.W., DeHaan, L.R., Eriksson, D., Gill, B.S., Holland, J., Hu, F., Hulke, B.S., Ibrahim, A.M., Jackson, W., Jones, S.S., Murray, S.C., Paterson, A.H., Ploschuk, E., Sacks, E.J., Snapp, S., Tao, D., Van Tassel, D.L., Wade, L.J., Wyse, D.L., and Xu, Y. 2010. Agriculture. Increased food and ecosystem security via perennial grains. Science 328(5986):1638-1639.

Hayes, R.C., Newell, M.T., DeHaan, L.R., Murphy, K.M., Crane, S., and Norton, M.R. 2012. Perennial cereal crops: An initial assessment of wheat derivatives. Field Crops Research 133:68-89.

Huggins, D.R. and Reganold, J.P. 2008. No-till: The quiet revolution. Scientific American 299(1):70-77.

Jackson, W. 2002. Natural systems agriculture: A truly radical alternative. Agriculture, Ecosystems and Environment 88: 111-117.

Jaikumar, N.S., Snapp, S.S., Murphy, K., and Jones, S.S. 2012. Agronomic assessment of perennial wheat and perennial rye as cereal crops. Agronomy Journal 104(6):1716-1726.

Kallas, Z., Serra, T., and Gil, J.M. 2010. Farmers' objectives as determinants of organic farming adoption: The case of Catalonian vineyard production. Agricultural Economics 41(5):409-423.

Kandel, H.J., Porter, P.M., Carr, P.M., and Zwinger, S.F. 2008. Producer participatory spring wheat variety evaluation for organic systems in Minnesota and North Dakota. Renewable Agriculture and Food Systems 23:228-234.

Kaufmann, P., Zemeckis, R., Skulskis, V., Kairyte, E., and Stagl, S. 2011. The diffusion of organic farming in Lithuania. Journal of Sustainable Agriculture 35(5):522-549.

Knowler, D. and Bradshaw, B. 2007. Farmers' adoption of conservation agriculture: A review and synthesis of recent research. Food Policy 32(1):25-48.

Lahmar, R. 2010. Adoption of conservation agriculture in Europe: Lessons of the KASSA project. Land Use Policy 27(1):4-10.

Läpple, D. 2010. Adoption and abandonment of organic farming: An empirical investigation of the Irish Drystock sector. Journal of Agricultural Economics 61(3):697-714.

Läpple, D. and Van Rensburg, T. 2011. Adoption of organic farming: Are there differences between early and late adoption? Ecological Economics 70(7):1406-1414. 
Lesser, W., Bernard, J., and Billah, K. 1999. Methodologies for ex ante projections of adoption rates for agbiotech products: Lessons learned from rBST. Agribusiness 15(2):149-162.

Mccann, E., Sullivan, S. Erickson, D., and Young, R.D. 1997. Environmental awareness, economic orientation, and farming practices: A comparison of organic and conventional farmers. Environmental Management 21(5):747-758.

Mercer, D.E. 2004. Adoption of agroforestry innovations in the tropics: A review. Agroforestry Systems 61-62(1-3): 311-328.

Morgan, K. and Murdoch, J. 2000. Organic vs. conventional agriculture: Knowledge, power and innovation in the food chain. Geoforum 31(2):159-173.

Murphy, K.M., Hoagland, L.A., Reeves, P.G., Baik, B.-K., and Jones, S.S. 2009. Nutritional and quality characteristics expressed in 31 perennial wheat breeding lines. Renewable Agriculture and Food Systems 24:285-292.

Murphy, K.M., Lyon, S.R., Balow, K.A., and Jones, S.S. 2010. Post-sexual-cycle regrowth and grain yield in Thinopyrum elongatum x Triticum aestivum amphiploids. Plant Breed 129:480-483.

Peterson, H.H., Barkley, A., Chacon-Cascante, A., and Kastens, T.L. 2012. The motivation for organic grain farming in the United States: Profits, lifestyle, or the environment? Journal of Agricultural and Applied Economics 44(2): $137-155$.

Pierpaoli, E., Carli, G., Pignatti, E., and Canavari, M. 2013. Drivers of precision agriculture technologies adoption: A literature review. Procedia Technology 8:61-69.

Pimentel, D., Cerasale, D., Stanley, R.C., Perlman, R., Newman, E.M., Brent, L.C., Mullan, A., and Chang, D.T.I. 2012. Annual vs. perennial grain production. Agriculture Ecosystems \& Environment 161:1-9.

Pingali, P.L., Rozelle, S.D., and Gerpacio, R.V. 2001. A crosscountry experiment in eliciting technological preferences. Economic Development and Cultural Change 49(3):591-609.

Prokopy, L.S., Floress, K., Klotthor-Weinkauf, D., and Baumgart-Getz, A. 2008. Determinants of agricultural best management practice adoption: Evidence from the literature. Journal of Soil and Water Conservation 63(5):300-311.

Race, D. and Curtis, A. 2007. Adoption of farm forestry in Victoria: Linking policy with practice. Australasian Journal of Environmental Management 14(3):166-178.

Rahm, M.R. and Huffman, W.E. 1984. The adoption of reduced tillage: The role of human capital and other variables. American Journal of Agricultural Economics 66 (4):405-413.

Rennings, K., Markewitz, P., and Vogele, S. 2013. How clean is clean? Incremental versus radical technological change in coal-fired power plants. Journal of Evolutionary Economics 23(2):331-355.

Ryan, R.L., Erickson, D.L., and De Young, R. 2003. Farmers' motivations for adopting conservation practices along riparian zones in a mid-western agricultural watershed. Journal of Environmental Planning and Management 46(1):19-37.

Sirrine, D., Shennan, C., and Sirrine, J.R. 2010. Comparing agroforestry systems' ex ante potential and ex post adoption: On-farm participatory research from southern Malawi. Agroforestry Systems 79(2):253-266.

Soltani, S., Azadi, H., Mahmoudi, H., and Witlox, F. 2014. Organic agriculture in Iran: Farmers' barriers to and factors influencing adoption. Renewable Agriculture and Food Systems 29:126-134.

Strong, N. and Jacobson, M.G. 2006. A case for consumerdriven extension programming: Agroforestry adoption potential in Pennsylvania. Agroforestry Systems 68(1):43-52.

Taus, A., Ogneva-Himmelberger, Y., and Rogan, J. 2013. Conversion to organic farming in the continental United States: A geographically weighted regression analysis. Professional Geographer 65(1):87-102.

Trozzo, K.E., Munsell, J.F., Chamberlain, J.L., and Aust, W.M. 2014. Potential adoption of agroforestry riparian buffers based on landowner and streamside characteristics. Journal of Soil and Water Conservation 69(2):140-150.

Valdivia, C. and Poulos, C. 2009. Factors affecting farm operators' interest in incorporating riparian buffers and forest farming practices in northeast and southeast Missouri. Agroforestry Systems 75(1):61-71.

Vanloqueren, G. and Baret, P.V. 2009. How agricultural research systems shape a technological regime that develops genetic engineering but locks out agroecological innovations. Research Policy 38(6):971-983.

Virk, D.S., Chakraborty, M., Ghosh, J., Prasad, S.C., and Witcombe, J.R. 2005. Increasing the client orientation of maize breeding using farmer participation in Eastern India. Experimental Agriculture 41:413-426.

Vitale, J.D., Godsey, C., Edwards, J., and Taylor, R. 2011. The adoption of conservation tillage practices in Oklahoma: Findings from a producer survey. Journal of Soil and Water Conservation 66(4):250-264. 